\title{
Determinants of Economic Growth and its Impact on Poverty in Lampung Province
}

\author{
Hasbullah $^{1}$, Wahyu Murti ${ }^{2}$, Muhammad Jasin ${ }^{3}$, Yudhinanto C Nugroho ${ }^{4}$ \\ \{hasbullah@umitra.ac.id ${ }^{1}$,wahyu_murti@borobudur.ac.id², moch.jasin1@borobudur.ac.id ${ }^{3}$, \\ yudhi@umitra.ac.id $\left.{ }^{4}\right\}$ \\ Universitas Borobudur, Jakarta, Indonesia ${ }^{1,2,3,4}$
}

\begin{abstract}
Abstrack. The aim of the research is to assess and investigate the impact of economic growth variables on poverty in Lampung Province, Indonesian., the main problem in this study is the slow economic growth that affects the poverty level in Lampung Province, especially poverty in urban areas and especially in rural areas. This research Explanatory or hypothesis-testing studies are used to explain and evaluate theories concerning the relationship between variables. Secondary data is gathered through documentation studies to be used as research data. as time-series data between 2004-2018 which is divided into 4 quarter periods. Research hypotheses about the effect between variables were tested and analyzed using multiple linear regression analysis recursively. The effect of the variable is based on the results of statistical tests using the t-test. economic growth on poverty gets a p-value of $0.0368<0.05$, which means that there is a large and negative impact between economic growth on poverty.
\end{abstract}

Keywords: Economic Growth; Poverty

\section{Introduction}

Lampung province is the veranda of Sumatra, and has a very strategic geographical position as the main gateway to the island of Sumatra. Lampung Province is also the only province outside Java which is closest to the state capital, Jakarta. Supported by a strategic position, Lampung province has a very From Java to Sumatra, and vice versa, it plays a vital role in land transportation routes and logistical distribution activities., Lampung province is also known as an agricultural and plantation area, many agricultural and plantation commodities are produced from the Lampung area. : such as coffee, cocoa, sugar cane, rubber, deep coconut and oil palm, along with their processing industries. With this very strategic position, the Lampung province does not necessarily make the Lampung people able to raise their standard of living for a better and more prosperous, even inversely, although the poverty rate in the Lampung province has decreased. According to BPS Lampung, the poverty rate was floated from the calculation of the results of the National Socio-Economic Survey, September 2018 reaching 13.01 percent or 1,091.60 thousand people.

Number and Percentage of the Poor Based on the area of residence, the poor are concentrated in rural areas with a poverty rate of 14.73 percent. Quite far adrift with urban poverty which is only 9.06 percent. In terms of the number of poor people, there are also 
significant differences, namely 230.20 thousand people in urban areas and 861.40 thousand people in rural areas.

Data from March 2018 the poverty rate of Lampung Province was 13.14 percent or $1,097.05$ thousand people. In other words, during the period March - September 2018 there has been a decrease in the number of poor people by around 5.45 thousand people. The Lampung poverty rate in September 2018 is still higher than the national poverty rate of 9.66 percent. Since March 2016, the percentage of poverty in Lampung Province has experienced a downward trend. This shows that the performance of local governments in overcoming poverty is right on target. Although in the March 2018 period, there was an increase in the percentage of poverty in the Lampung province, the poverty rate fell again in the September 2018 period. This is not in line with what happened at the national level so that the gap between the national poverty rate and the Lampung Province poverty rate is widening.

BPS employs the concept of being able to meet basic requirements to measure poverty (basic needs approach). Poverty is defined as an inability to meet basic food and non-food needs as assessed by expenditures in this technique. The Poverty Line (GK) is calculated, which is made up of two parts: the The GKM (Food Poverty Line) and NFP (Non-Food Poverty Line) are two different types of poverty lines (GKNM). People who earn less than the poverty level on a monthly basis are considered poor. The Food Poverty Line (GKM) is the amount spent on basic food necessities, which is equal to $2100 \mathrm{kcal}$ per capita per day. The Global Keyline for Non-Food Poverty (GKNM) is the bare minimum for housing, clothing, education, and health care.. During 2014 to 2019, the number of poor people in Lampung Province decreased, from around 405,000 people (2014) to around 301 thousand (2019). This condition is of course followed by a decrease in the percentage of the poverty rate, where in 2014, the poverty rate reached 20.46 percent, dropping to 14.30 percent in 2019 .

In 2019, the highest poverty rate occurred in North Lampung Regency (28.19 percent), followed by East Lampung (21.06 percent), while the lowest occurred in Tulang Bawang Barat Regency ( 7.63 percent). In development efforts, it is not uncommon for the results achieved to be not in accordance with what is desired. The success of development performance in an area can be judged by how much the most basic problems can be overcome, such as poverty, unemployment, food security and other basic problems. This issue is a concern for government administrators (BPS 2015). The indicator that is often used in the analysis of Economic growth is the result of economic development. The term "high economic growth" refers to an increase in economic activity from one year to the next. So economic growth indicates how much economic activity will increase people's income over time, because economic activity is essentially a process of using production factors to produce output that will increase people's income as owners of production factors.

\section{Theoretical Framework}

Economic growth, defined as the process of growing output through time, is a key indicator of a country's success or region's development (Todaro, 2005). Development with High economic growth can increase the ability of people's living standards and welfare through a development process carried out by mobilizing capabilities and utilizing existing resources. Lampung's economic growth is also obtained from production factors, especially with the availability of labor and technology, employment is the goal of macroeconomic policy in addition to increasing the rate of economic growth, price stability, and strong export 
and import trade will affect the exchange rate and foreign exchange rate. So that the number of workers will be absorbed and the number of unemployed will decrease.

Regional economic development is a process in which local governments and other members of society collaborate to manage diverse existing resources and create new jobs and support the growth of economic activity in the area. (Mudrajad 2004). Several economic activities, such as improved productivity and income per capita of the population, is associated with the development of a country or region. so that there is an improvement in the level of welfare. The foreign trade sector, namely exports and imports, must promote good economic growth. Economic development is a multi-faceted term that comprises structural, behavioral, and institutional changes in addition to greater economic growth., reducing inequality in distribution and eradicating poverty. Todaro (2010). Rapid economic growth and low income inequality can be achieved but they cannot be achieved at the same time. (Shin, 2012). Achieving these development targets requires good economic development planning. This is because in general the economic development of a region is closely related to its economic potential and characteristics which generally differ from one region to another.

According to Soemitro in (M.A. Subing 2013, p.383), The process of increasing the production of products and services in people's economic activities is the foundation of economic growth., economic change has a more powerful meaning and includes changes in the overall economic structure of society. And it is also stated that there are three main characteristics of economic growth, namely: (a) The rate of growth of income per capita in a real or real sense. (b) the distribution of the labor force according to the sector of production activity which is the source of livelihood, (c) the pattern of population distribution.

To assess the economic development's success Economic development success can be judged using numerous assessment models, according to Wirasasmita (2009, p.128).: (1) Economic Growth, (2) Growth of GDP per capita, (3) The Physical Quality Of Life Index ( PQLI). (4) The Human Development Index (HDI), (5) Fulfillment of Basic Needs, (6) Clean Economic Indicators. In addition, according to (Parsiyo and Widya, 2013) the indicator that determines the success of national economic development is economic growth. Economic structure, quality of life index, urbanization and human development index, health, and education.

\section{Methodology}

The research method used in this research is the quantitative method. Sugiyono (2018) suggests that it is said to be a quantitative method because the research data is in the form of numbers and the analysis uses statistics. In this study, there are two variables, namely the independent variable $(\mathrm{X})$ namely Economic Growth and the dependent variable (Y) namely poverty.

\section{Result and Discussion}

The gross added value of all goods and services created or produced in a country's domestic territory as a result of various economic activities within a given period, regardless of whether the production factors are owned by residents or non-residents, is referred to as Gross Regional Domestic Product (GRDP). The production, expenditure, and income approaches, which are given on the basis of current prices and constant (real) prices, are the 
three approaches that can be used to prepare the GRDP. The GRDP at current prices, also known as nominal GRDP, is calculated using prices in effect during the computation period to determine the economy's structure. Meanwhile, GRDP has remained stable. (real) prices is a measure of economic growth that is based on prices in the base year.

Based on the results of statistical tests using the t-test that the effect of the variable economic growth on poverty gets a p-value of $0.0368<0.05$, which means that there is a negative and significant effect between economic growth on poverty. The constant value of 5.7978 indicates that if the value of economic growth $(\mathrm{X})$ is not very small, then the average number of poverty levels in Lampung Province is 5.7978 people. The value of the regression coefficient of economic growth (X) of -1.1612 indicates With the premise of cateris paribus, if the value of economic growth increases by one percent, the poverty rate in Lampung Province decreases by 1.1 percent, and vice versa if the value of economic growth decreases by one percent. decreases by 1 percent then causes an increase in poverty by 1.1 percent. This means that between economic growth and the poverty rate there is a negative or inverse relationship because an increase in economic growth will reduce poverty in Lampung Province.

According to the results of the regression, there is a negative and substantial association between economic growth and poverty. This means that any rise in economic growth has an impact on poverty levels. The findings of this study are consistent with those of previous research. Chairul Nizam, Abu Bakar Hamzah (2013, p.8), resulting in his research that the variable Economic Growth has a negative and significant effect on poverty. Another study that is in line with the results of this study was also conducted by Siti Aminah (2016) which resulted in her research that the variable economic growth had a negative and significant effect on poverty. The problem of poverty is the main challenge for the development of Lampung Province in an effort to realize community welfare. Although the poverty rate of Lampung Province for the last 3 (three) years has continued to show a decline, the still high poverty rate of Lampung Province compared to the national level indicates that Lampung Province still has to pay attention to poverty as a priority in development policies.

In the Lampung Provincial RPJMD Vision 2015-2019 it is stated that the people of Lampung want to make development an aspiration, a road map or strategic step, community energy and community identity to move in a more advanced direction, both comparatively and competitively. This vision is the final condition of the Lampung region and region desired by all stakeholders in Lampung Province in the 2015-2019 period with the vision of "Lampung Forward and Prosperous 2019". Improving the Quality of Education, Health, Science, Technology and Innovation, Community Culture, and Tolerance of Religious Life is the mission of the Province of Lampung in an effort to develop and strengthen the quality of human resources (HR) by developing and improving the quality of education in all lines, types and levels. The development of quality human resources is supported by increasing women's empowerment and child protection, physical quality (sports), health services in every life cycle and controlling population growth.

The Lampung Provincial Government does not yet have a regional regulation on poverty reduction, but poverty reduction policies in Lampung Province are contained in several government documents. Poverty is an urgent problem in Lampung Province and requires systematic, integrated and comprehensive handling and approach stepsAccording to the results of the regression, there is a negative and significant relationship between economic growth and poverty. This means that any rise in economic growth has an impact on poverty levels. The findings of this study are consistent with the previous research., guarantee efforts are needed which include targeting, program design and integration, monitoring and evaluation, as well as budget effectiveness. Poverty reduction efforts will only become a necessity if they do 
not get full support from the local government, considering that local governments are the main driving force in the current era of regional autonomy.

\section{References}

[1] Adiwarman, karim 2014. Ekonomi Makro Islam. Jakarta PT. Raja Grafindo

[2] Andi Rokhmat, Hadi Sasana dkk (2020 h. 70-88) Pengaruh Pembangunan Infrastruktur Jalan Raya Provinsi, Air Bersih, Hotel, Penginapan dan Restoran Terhadap Pertumbuhan Ekonomi (PDRB) http://journals.USM.ac.id/index.php/jreb

[3] Aygul Isayeva. "Comparative Analysis of Economics Factor Affecting Export and Import in the Countries of South Caucasus". 2012.

[4] Astuti dan Ayuningtyas. 2018. Pengaruh Ekspor dan Inpor Terhadap Pertumbuhan Ekonomi di Indonesia. Jurnal Ekonomi dan Studi Pembangunan

[5] Asbiantari. 2016 Pengaruh Ekspor Terhadap Pertumbuhan ekonomi Indonesia. Jurnal Ekonomi IPB. jurnal,ipb.ac.id

[6] Aziz Septian, Mawardi dan Khairu Rizki. Pengaruh Inflasi dan Tingkat Pengnangguran terhadap Pertumbuhan Ekonom di Indonesia I-Economic, vol. 2 No. 1 Juli 2016)

[7] Badan Pusat Statistik, 2015. Lampung dalam Angka :BPS Provinsi Lampung

[8] Bayu Dwi Dharma, Sjamsu Djohan. 2015 Pengaruh Investasi dan Inflasi terhadap Kesempatan Kerja melalui Pertumbuhan Ekonomi di Kota Samarinda

[9] Boediono. 2001. Ekonomi Moneter, Seri Sinopsis Pengantar Ilmu Ekonomi. Yogyakarta: BPFE.

[10] Bullish dan Bearish. Jurnal Riset Ekonomi dan Manajemen, vol.3 no.3.

[11] Case, karl E. \& Fair, Ray C.. 2007. Prinsip-Prinsip Ekonomi Edisi 8 Deterjemahkan Oleh Y. Andri Zaimur. Erlangga; Jakarta

[12] Citra Ramayai. Pengaruh Investasi pemerintah, Investasi Swasta, Inflasi, Eksport, tenaga Kerja dan Produktivitas Tenaga Kerja terhadap Pertumbuhan Ekonomi di Indonesia. Jurnal Of Economic and Economic Education Vol.1, No.2 (203-207) 2013.

[13] Chairul Nizar, Abu Bakar Hamzah dkk (2013 h.8) Pengaruh Investasi dan Tenaga Kerja Terhadap Pertumbuhan Ekonomi Serta Hubunganya terhadap Tingkat kemiskinan di Indonesia

[14] David Canning dan Peter Pedroni (The Effect of Infrastructure On Long Run Economic Growth 2014: 57) International Journal of Energy Economics and Policy Vol. 4, No. 4, 2014, pp.578-587 ISSN: 2146-4553

[15] Deni Iswanto. “ Analisis Factor Factor yang Mempengaruhi Ekspor Kayu Lapis Indonesia ke Jepang ". 2013

[16] Dewi Ernita, Syamsul Amar, Efrizal Syofyan. (2013) Analisis Pertumbuhan Ekonomi, Investasi dan Konsmsi di Indonesia. Jurnal Ekonomi Vol. 1, No. 02.193

[17] Dewi, Ni Wayan Nuryanti, dan made kembar sri budi 2015, pengaruh pendapatan Asli Daerah dan Dana bagi Hasil terhadap pertumbuhan ekonomi melalui belanja langsung di Prov. Bali, E. Jurnal Ekonomi Pembangunan Universitas Udayana, 4 (II) 1391-1420

[18] Dewi Navulan Sari, Moh. Nur Syechalad dan Sofyan. “ Analisis Faktor Faktor yang Mempengaruhi Ekspor Kopi Arabica Aceh ". 2013

[19] Dinas Tenaga Kerja dan Transmigrasi, 2016. Disnakertrans Provinsi Lampung

[20] Dinas Tenaga Kerja dan Transmigrasi, 2016 . Disnakertrans, UMP Lampung Provinsi Lampung. 
[21] Febry, Chindy Rori dkk, 2016 Analisis Pengaruh Pendapatan Asli Daerah terhadap pertumbuhan Ekonomi di Provinsi Sulawesi Utara.

[22] Gujarati, Damodar. 2006, Ekonometrika Dasar, Erlangga, Edisi Kelima, Jakarta.

[23] Ginting, Ari Mulianta. 2013. Pengaruh Nilai Tukar Terhadap Ekspor Indonesia. Jurnal Ekonomi Pembangunan. Jakarta.

[24] Ginting, 2017. Analisis Pengaruh Ekspor Terhadap pertumbuhan Ekonmi indonesia Jurnal Kemendag.go.id 